\title{
PERAN KEPALA SEKOLAH DALAM MENINGKATKAN MUTU PENDIDIKAN
}

\author{
Oleh \\ Muh. Fitrah \\ Institut Agama Islam Muhammadiyah Bima \\ fitrahmath@gmail.com
}

Diterima 01 Januari 2017, direvisi 07 Januari 2017, diterbitkan 28 Pebruari 2017

\begin{abstract}
This writing has main purpose that is to know head master's role in improving educational quality, leadership, duty, and headmaster's role in improving educational quality, leardership, duty, and headmaster's role in order to produce process and product of quality education. Educational quality is our hope in facing strict life exchange in several sectors especially in education sectors for better future. For the sake of making educational quality, this needs role of leaders in educational institutes. One of them is headmaster because it is the pioneer is moving all changes to go to educational quality. Headmaster's duty is not only leading ceremony, waiting incoming letter to be signed but also making a good quality of education in school. Specifically headmaster's role in improving quality of education are doing monitoring, evaluating continually toward seccessful program determined, planning and arranging word plan agreed with improving needs of educational quality which orients on school's mission, making intensive commumication with teachers, students, student's parents and society.
\end{abstract}

\section{Keywords: headmaster, school, educational quality}

\section{PENDAHULUAN}

Salah satu agenda reformasi di bidang pendidikan adalah pendelegasian kewenangan pengelolaan pendidikan pada pemerintah daerah, sebagaimana UU No. 23 tahun 2014. UU tersebut menyebut bahwayang akan menjadi kewenangan pemerintah daerah tidak sepenuhnya yaitu terbatas pada aspek pembiayaan, sumber daya manusia dan saranaprasarana. Sementara untuk aspek-aspek menyangkut kurikulum, pembelajaran, evaluasi dan pengukuran, sarana dan alat pembelajaran, metode dan waktu belajar, buku serta alokasi belanja dan penggunaan anggaran, semuanya menjadi kewenangan sekolah.Oleh karena itu kepala sekolah dan para guru dituntut bertanggung jawab terhadap kualitas proses dan hasil belajar guna meningkatkan mutu pendidikan secara nasional (Rosyada, 2013).

Mengacu pada UU yang direvisi sebanyak tiga kali dari tahun 1999, 2004, dan 2014 menunjukkan bahwa era reformasi pendidikan yang sangat monumental dalam sejarah pendidikan di Negara Repeblik Indonesia ini, dimana otoritas yang sangat besar diberikan langsung pada sekolah. Sekolah bisa mengembangkan inovasinya masing-masing dalam mengembangkan perlakuan pada siswa dalam belajar, bahkan sekolah diberi kewenangan untuk menetapkan kebijakan 
tersendiri, misalkan saja disekolah apakah akanfullday school atau partday school dalam penggunaan waktu belajar. Selain itu, apakah sekolah akan menyusun sendiri buku teks yang diajarkan sesuai dengan kurikulum yang disepakati, atau membeli buku-buku karya guru lainnya. Dalam hal ini, hal terpenting adalah siswa berprestasi, siap diuji, sesuai dengan standar kompetensi yang ditetapkan. Karena itu, bila prestasi siswa menurun, maka masyarakat tidak bisa menyalahkan kantor dinas pendidikan baik kabupaten dan kota. Sebaliknya, mereka bisa bertanya pada kepala sekolah dan para gurunya, karena soal kurikulum dan pembelajaran seluruhnya menjadi kewenangan penuh ditangan sekolah.

Sejalan dengan tantangan kehidupan global, pendidikan merupakan hal yang sangat penting karena pendidikan salah satu penentu mutu sumber daya manusia. Dewasa ini keunggulan suatu bangsa bukan lagi diidentikkan dengan melimpahnya ruangnya kekayaan alam yang ada, akan tetapi lebih kepada keunggulan sumber daya manusianya, karena mutu sumber daya manusia berkontribusi positif bagi mutu pendidikan. Mutupendidikan sering dinilai dengan kondisi yang baik, syarat yang terpenuhi, serta komponen yang komplit dalam pendidikan. Komponen-komponen tersebut adalah masukan, proses, keluaran, tenaga kependidikan, sarana dan prasarana, serta biaya.

Kepala sekolah sebagai kunci pendorong bagi perkembangan dan kemajuan sekolah serta bertanggungjawab untuk meningkatkan akuntabilitas keberhasilan siswa dan programnya. Agar hal demikian tercapai dengan baik, maka kepemimpinan kepala sekolah perlu diberdayakan, sehingga kepala sekolah mampu berperan sesuai dengan tugas, wewenang, dan tanggungjawabnya(Purwanti, Murniati dan Yusrizal, 2014). Kepala sekolah harus pandai memimpin kelompok dan pendelegasian tugas dan wewenang.
Bercermin pada penjelasan tersebut, maka kepala sekolah mendapat tuntutan peran yang sangat besar. Dia harus kuat dan memiliki gaya kepemimpinan yang kuat untuk mendorong seluruh gurunya bekerja total dalam mendidik siswa-siswinya, memiliki visi untuk kemajuan sekolah, konsisten dengan visinya, tapi tetap demokratis dan menghargai pandangan para staf. Kepala sekolah juga harus memiliki ekspektasi yang baik pada para siswanya, memberikan penguatan keterampilan dasar untuk siswa-siswinya, sehingga bisa berkembang dengan baik dalam profesi apapun, dan mampu menciptakan suasanan yang kondusif untuk para guru dan karyawan serta menciptakan suasana yang nyaman untuk siswa (Rosyada, 2013).

Dua faktor yang dapat menjelaskan mengapa upaya perbaikan mutu pendidikan selama ini tidak berhasil. Pertama, strategi pembangunan pendidikan selama ini lebih bersifat input oriented. Strategi yang demikian lebih bersandar kepada asumsi bahwa bilamana semua input pendidikan telah dipenuhi, seperti penyediaan materi ajar dan alat belajar lainnya, penyediaan sarana pendidikan, pelatihan guru dan tenaga kependidikan lainnya, maka secara otomatis sekolah akan dapat menghasilkan output yang bermutu sebagai mana yang diharapkan. Ternyata strategi input-output tidak berfungsi sepenuhnya di lembaga pendidikan, melainkan hanya terjadi dalam institusi ekonomi dan industri (Hanushek, 1981).Kedua, pengelolaan pendidikan selama ini lebih bersifat macro-oriented, diatur oleh jajaran birokrasi di tingkat pusat. Akibatnya, banyak faktor yang diproyeksikan di tingkat pusat tidak terjadi atau tidak berjalan sebagaimana mestinya di tingkat sekolah.

Selaras dengan regulasi tentang pelimpahan otoritas dari pusat ke daerah dan sekolah, peran kepala madrasah menjadi sangat vital. Peran kepala sekolah akan sangat menentukan maju atau mundurnya pendidikan. Tulisan ini 
membahas tentang peran kepala sekolah dalam meningkatkan mutu pendidikan.

\section{PEMBAHASAN}

\section{Mutu Pendidikan Di Sekolah}

Salah satu acuan indikator keberhasilan kepala sekolah diukur dari mutu pendidikan yang ada di sekolah yang dipimpinnya. Dalam konteks pendidikan, pengertian mutu mencakup input, proses, dan output pendidikan (Depdiknas, 2001). Input pendidikan adalah segala sesuatu yang harus tersedia karena dibutuhkan untuk berlangsungnya proses. Proses pendidikan merupakan berubahnya sesuatu menjadi sesuatu yang lain dengan mengintegrasikan input sekolah sehingga mampu menciptakan situasi pembelajaran yang menyenangkan, motivasi dan minat belajar yang tinggi.Output pendidikan merupakan kinerja sekolah yang dapat diukur dari kualitasnya, produktivitasnya, efisiensinya, inovasinya, dan moral kerjanya. Dalam konsep yang lebih luas, mutu pendidikan mempunyai makna sebagai suatu kadar proses dan hasil pendidikan secara keseluruhan yang ditetapkan sesuai dengan pendekatan dan kriteria tertentu (Surya, 2002).

Menurut Townsend dan Butterworth (1992)beberapa halyang menjadi penentu terwujudnya proses pendidikan yang bermutu, antara lain: a) keefektifan gaya kepemimpinan kepala sekolah; b) partisipasi aktif dan rasa tanggung jawab guru dan staff; c) keberlangsungan proses belajar-mengajar yang efektif;d) kurikulum yang relevan; e) memiliki visi dan misi yang terarah; f) iklim sekolah yang kondusif, dan g) keterlibatan orang tua dan masyarakat secara instrinsik.

Jika dipahamai secara sederhana dari beberapa unsur diatas bahwa konsep mutu pendidikan bukan semata-mata terfokus pada penyediaan faktor input pendidikan, akan tetapi lebih memperhatikan faktor dalam proses pendidikan. Input pendidikan merupakan hal yang mutlak harus ada dalam batas-batas tertentu tetapi tidak menjadi jaminan dapat secara otomatis meningkatkan mutu pendidikan.

Pendidikan nasional dari tahun 2002 ditandai dengan berbagai perubahan yang datang, serempak, dan dengan frekuensi yang sangat tinggi. Belum tuntas sosialisasi perubahan yang satu, datang perubahan yang lain. Beberapa inovasi yang mendominasi panggung pendidikan selama beberapa tahun terakhir,yaitu: manajemen berbasis sekolah, peningkatan mutu berbasis sekolah, kurikulum berbasis kompetensi, pengajaran/pelatihan berbasis kompetensi, pendidikan berbasis luas, pendidikan berbasis masyarakat, evaluasi berbasis kelas, evaluasi berbasis siswa dikenal juga dengan evaluasi portofolio, manajemen pendidikan berbasis lokal, pembiayaan pendidikan berbasis masyarakat, belajar berbasis internet, kurikulum 2013 dan pembentukan dewan sekolah dan dewan pendidikan kabupaten/kota dan masih banyak lainnya.Fenomena yang menarik adalah perubahan itu umumnya memiliki sifat yang sama. Bila diamati lebih jauh, perubahan yang berbasis itu umumnya dari atas ke bawah; dari pusat ke daerah; dari pengelolaan di tingkat atas menuju sekolah; dari pemerintah ke masyarakat; dari sesuatu yang sifatnya nasional menuju yang lokal.

Oleh karenaitu, banyak inovasi pendidikan yang diluncurkan di Indonesia dewasa ini kurang dihayati secara penuh oleh pelaksananya (termasuk kepala sekolah), di samping secara konseptual, serba tergesa-gesa, serba instan, targetnya tidak realistik, didasari asumsi yang linier seakan-akan suatu inovasi akan bergulir mulus begitu diluncurkan dan secara implisit dimuati obsesi demi menanamkan aset politik di masa depan.

\section{Kualitas Pendidikan Kita}

Istilah kualitas pendidikansangat mudah dikatakan, namun sangat sukar didefinisikan, karena pemaknannya terus berkembang dan menjadi perhatian semua orang di dunia. 
Kualitas terbagi dalam dua bagian utama, yaitu kualitas absolut dan relatif. Oleh sebab itu, ukuran kualitas dalam manajemen pendidikan seringkali menggunakan ukuran dalam pengertian kualitas relatif, yakni kualitas yang masih berpeluang untuk ditingkatkan, direvisi secara dinamis, sehingga pengertiannya menjadi pencapaian standar tertentu yang telah ditetapkan bersama-sama sebelum memulai pekerjaan, baik dalam produk barang, jasa maupun lainnya (Rosyada, 2013).

Pendidikan termasuk produk jasa, dan pendidikan selalu ada standar yang dirumuskan bersama oleh masyarakat dan diusulkan pada pemerintah untuk ditetapkan menjadi Peraturan Pemerintah, Peraturan Menteri, atau paling tidak Peraturan Daerah. Dalam Peraturan Pemerintah No.19 Tahun 2005 dan direvisi menjadi PP Nomor 13 Tahun 2015, ditetapkanbahwa kualitas pendidikan di Indonesia diukur dengan delapan standar, yakni standar isi, standar proses; standar kompetensi lulusan; standar pendidik dan tenaga kependidikan; standar sarana dan prasarana; standar pengelolaan; standar pembiayaan; dan standar penilaian pendidikan.

Sergiovanni (1987) memaparkan kualitas pendidikan yang diterima di sekolah akan menghasilkan kualitas belajar sebagai produk dari ke efektifan manajerial kepala sekolah.Dengan demikian, ukuran pencapaian kualitas pendidikan di Indonesia sangat ditentukan oleh pencapaian masing-masing sekolah dalam mengimplementasikan program dan proses layanan menuju pada standar minimal hasil pendidikan yang diharapkan dalam seluruh standar isi dan standar kompetensi lulusan, didukung dengan terpenuhinya standar proses, sarana dan parasarana, pengelolaan, penilaian, pembiayaan dan lain-lain. Prestasi kerja kepala sekolah dipengaruhi oleh variabelvariabel kepemimpinan, pengetahuan manajemen, ketahan-malangan, dan budaya organiasi sekolah (Ahmad, 2013).
Jeanette\&Miske (2000) pernah melakukan penelitian teoretik untuk mengevaluasi dan mengukur kualitas penyelenggaraan pendidikan untuk anak-anak di tingkat sekolah dasar, dengan mengukur limaaspek utama, antara lain: 1) siswa; 2) lingkungan; 3) prosespembelajaran; 4) bahan ajar harus mencerminkan penguasaan basic skill, dan 5) outcome.Sementara Priscilla (2007) berdasarkan penelitiannya bahwa untuk mengevaluasi kualitas pengelolaan dan penyelenggaraan pendidikan yang mempersiapkan aktifitas anak setelah sekolah ditinjau dari dua katerori yaitu struktur dan proses. Kualitas struktur diukur dalam tiga variabel, antara lain; 1) rasio siswa dengan staff, ukuran rombongan belajar, dan program pengelolaan sekolah; 2) kualifikasi staf, level pendidikan dan pelatihan, dan 3) lamanya waktu layanan pendidikan.

Sekolah itu berkualitas atau tidak sangat bergantung pada pola kepemimpinan kepala sekolah, karena dialah pimpinan tertinggi di sekolah, dan dialah yang bisa mengambil keputusan dalam segala hal, seperti: guru yang direkrut, penugasan guru, rotasi guru, pembinaan guru dan bahkan promosi kepangkatan guru. Semakin guru itu bekerja dengan penuh antusias, bermotivasi baik, dinamis mengikuti kemajuan baik teori, instrumen, teknologi maupun kebijakan pemerintah, maka akan semakin tinggi produktifitas sekolah.

Pendefinisian kepemimpinan banyak sekali dipaparkan oleh para ahli baik secara umum maupun secara khusus, karena sesungguhnya kepemimpinan merupakan salah satu faktor yang sangat penting dalam suatu organisasi karena sebagian besar keberhasilan dan kegagalan suatu organisasi ditentukan oleh kepemimpinan dalam organisasi tersebut. Artinya bahwa kepemimpinan berperan sebagai penggerak segala sumber daya manusia dan sumber daya lain yang ada dalam organisasi 
(Sedarmayanti, 2010).Hal lain yang yang bisa diartikan bahwa kepemimpinan adalah bagian penting dalam manajemen (Sri, 2013), kemampuan meyakinkan dan menggerakkan orang lain agar mau bekerja sama di bawah kepemimpinannya sebagai suatu tim untuk mencapai suatu tujuan tertentu (Rivai, 2004; Hersey dan Ken Blanchard, 2005; Sadili Samsudin,2006; Purwati, 2013).Berdasarkan beberapa definisi tersebut disimpulkan bahwa kepemimpinan adalah kemampuan yang dimiliki seseorang dalam mempengaruhi orang lain untuk bekerja sama agar mau bertindak dan berbuat dalam mencapai tujuan bersama.

Kepemimpinan sekolah adalah kapasitas pemimpin sekolah dalam memahami dan mengartikulasikan visi, misi, dan strategi sekolah, meyakini bahwa sekolah adalah tempat untuk belajar, mempengaruhi, memberdayakan, membimbing, membentuk kultur, menjaga integritas, berani mengambil resiko sebagai pionir dalam pembaharuan, memotivasi, mendudukkan sumber daya manusia lebih tinggi dari pada sumber daya-sumber daya yang lainnya, menghargai orang lain, dan selalu proaktif.

Sebagaimana dikemukakan dalam Pasal 12 ayat 1 PP 28 tahun 1990 bahwa kepala sekolah bertanggung jawab atas penyelenggaraan kegiatan pendidikan, administrasi sekolah, pembinaan tenaga kependidikan lainnya, dan pendayagunaan serta pemeliharaan sarana dan prasarana.Kepala sekolah diangkat melalui prosedur serta persyaratan tertentu yang bertanggung jawab atas tercapainya tujuan pendidikan melalui upaya peningkatan profesionalisme tenaga kependidikan yang mengimplikasikan meningkatkanya prestasi belajar. Kepala sekolah yang professional akan berfikir untuk membuat perubahan tidak lagi berfikir bagaimana suatu perubahan sebagaimana adanya sehingga tidak terlindas oleh perubahan tersebut. Untuk mewujudkan kepala sekolah yang profesional tidak semudah membalikkan telapak tangan, semua itu butuh proses yang panjang.

Namun jika kita berkaca pada kenyataan di disekolah disetiap daerah tentu kepala sekolah masih banyak yang tidak menjalankan tugas dan fungsinya sebagai pemimpin pendidikan. Ini disebabkan karena dalam proses pengangkatannya tidak ada trasnparansi, rendahnya mental kepala sekolah yang ditandai dengan kurangnya motivasi dan semangat serta kurangnya disiplin dalam melakukan tugas, dan seringnya datang terlambat serta banyak faktor penghambat lainnya untuk meningkatkan kualitas pendidikan yang mengimplikasikan rendahnya mutu pendidikan.

Ketercapaian tujuan pendidikan sangat bergantung pada kecakapan dan kebijaksanaan kepemimpinan kepala sekolah yang merupakan salah satu pemimpin pendidikan. Karena kepala sekolah merupakan seorang pejabat yang profesional dalam organisasi sekolah yang bertugas mengatur semua sumber organisasi dan bekerjasama dengan guru-guru dalam mendidik siswa untuk mencapai tujuan pendidikan.

Banyak faktor penghambat tercapainya kualitas kepemimpinan seorang kepala sekolah seperti proses pengangkatannya tidak transparan, rendahnya mental kepala sekolah yang ditandai dengan kurangnya motivasi dan semangat serta kurangnya disiplin dalam melakukan tugas dan seringnya datang terlambat, wawasan kepala sekolah yang masih sempit serta banyak faktor lain yang menghambat kinerja seorang kepala sekolah untuk meningkatkan kualitas pendidikan pada lembaga yang dipimpinnya. Ini mengimplikasikan rendahnya produktivitas kerja kepala sekolah yang berimplikasi juga pada mutu. Senada dengan hasil penelitian Sri, Yusrizal, \&Nasir(2016) salah satu kendala dalam meningkatkan mutu pendidikan adalah kepala sekolah yang kurang tepat waktu dalam melaksanakan program peningkatan mutu. 
Dalam melaksanakan fungsi kepemimpinannya, kepala sekolah harus melakukan pengelolaan dan pembinaan terhadap seluruh komponen sekolah melalui kegiatan administrasi, manajemen dan kepemimpinan yang sangat tergantung pada kemampuan manajerial seorang kepala sekolah. Hasil penelitian dari Busrin, Aunurrahman, \&Aswandi (2014) menunjukkan bahwa terdapat hubungan yang signifikan antara supervisi pengawas dan kemampuan manajerial kepala sekolah secara bersama-sama dengan kinerja guru.

\section{Peranan Sang Kepala Sekolah dalam Meningkatkan Mutu Pendidikan}

Peranan kepala sekolah dalam rangka meningkatkan mutu pendidikan sangat penting karena dapat mempengaruhi berhasil dan tidaknya mutu pendidikan itu sendiri. Secara garis besar, ruang lingkup tugas kepala sekolah dapat diklasifikasikan ke dalam dua aspek pokok, yaitu pekerjaan di bidang administrasi sekolah dan pekerjaan yang berkenaan dengan pembinaan profesional kependidikan.

Menurut persepsi banyak guru, keberhasilan kepemimpinan kepala sekolah terutama dilandasi oleh kemampuannya dalam memimpin. Kunci bagi kelancaran kerja kepala sekolah terletak pada stabilitas dan emosi, serta rasa percaya diri. Hal ini merupakan landasan psikologis untuk memperlakukan stafnya secara adil, memberikan keteladanan dalam bersikap, bertingkah laku dan melaksanakan tugas.Dalam konteks ini, kepala sekolah dituntut untuk menampilkan kemampuannya membina kerja sama dengan seluruh personal dalam iklim kerja terbuka yang bersifat kemitraan, serta meningkatkan partisipasi aktif dari orang tua murid.

Kepala sekolah sebagai komunikator bertugas menjadi perantara untuk meneruskan instruksi kepada guru, serta menyalurkan aspirasi personal sekolah kepada instansi kepada para guru, serta menyalurkan aspirasi personel sekolah kepada instansi vertikal maupun masyarakat. Pola komunikasi dari sekolah pada umumnya bersifat kekeluargaan dengan memanfaatkan waktu senggang mereka. Alur penyampaian informasi berlangsung dua arah, yaitu komunikasi topdown danbottom-up.

Dalam bidang pendidikan, yang dimaksud dengan mutu memiliki pengertian sesuai dengan makna yang terkandung dalam siklus pembelajaran.Secara ringkas dapat disebutkan beberapa kata kunci pengertian mutu, yaitu: sesuai standar, sesuai penggunaan pasar/ pelanggan, sesuai perkembangan kebutuhan, dan sesuai lingkungan globa. Adapun yang dimaksud mutu sesuai dengan standar, yaitu jika salah satu aspek dalam pengelolaan pendidikan itu sesuai dengan standar yang telah ditetapkan.

Dalam pandangan masyarakat umum sering dijumpai bahwa mutu sekolah dapat di tinjau dari ukuran gedung yang mewah. Ada pula masyarakat yang berpendapat bahwa kualitas sekolah dapat dilihat dari jumlah lulusan sekolah tersebut yang diterima di jenjang pendidikan selanjutnya. Untuk dapat memahami kualitas pendidikan formal di sekolah, perlu kiranya melihat pendidikan formal di sekolah sebagai suatu sistem. Selanjutnya mutu sistem tergantung pada mutu komponen yang membentuk sistem, serta proses yang berlangsung hingga membuahkan hasil.

Dalam pelaksanaan manajemen peningkatan mutu, kepala sekolah harus senantiasa memahami sekolah sebagai suatu sistem organisasi. Kepala sekolah dalam membangun sumber daya manusia melalui manajemen personalia (Suwardi, 2014).Secara umum Slamet (2000) menjelaskan karakteristik kepala sekolah tangguh, yaitu: a) memiliki wawasan jauh kedepan dan tahu tindakan apa yang harus dilakukan serta paham benar tentang cara yang akan ditempuh; b) memiliki kemampuan mengkoordinasikan dan menyerasikan seluruh sumberdaya terbatas yang ada; c) memiliki kemampuan mengambil keputusan, memobilisasi sumberdaya yang ada, 
toleransi terhadap perbedaan, dan d) memiliki kemampuan memerangi musuh-musuh kepala sekolah, yaitu ketidakpedulian, kecurigaan, tidak membuat keputusan, mediokrasi, imitasi, arogansi, pemborosan, kaku, dan bermuka dua dalam bersikap dan bertindak.

Adapun peran kepala sekolah dalam meningkatkan mutu pendidikan, yang meliputi perannnya sebagai edukator, manajer, administrator, supervisor, leader, inovator, dan motivator (Mulyasa, 2003; Vivi, 2013).

1) Kepala sekolah sebagai edukator, kepala sekolah bertugas untuk membimbing guru, tenaga kependidikan, siswa, mengikuti perkembangan iptek, dan memberi teladan yang baik.Seperti pemaparan dari Vivi (2013) bahwa untuk menciptakan iklim sekolah yang kondusif diperlukan kerjasama atau hubungan yang harmonis antara seluruh warga sekolah dan tidak hanya menjadi tanggung jawab kepala sekolah semata.Oleh karena itu upaya yang dapat dilakukan kepala sekolah dalam meningkatkan kinerjanya sebagai edukator, khususnya dalam peningkatan kinerja tenaga kependidikan dan prestasi belajar peserta didik adalah mengikutsertakan guru-guru dalam pendidikan lanjutandengan cara mendorong para guru untuk memulai kreatif dan berprestasi.

2) Kepala sekolah sebagai manajer, mempunyai fungsi:menyusun perencanaan, mengkoordinasikan kegiatan, melakukan pengawasan, melakukan evaluasi terhadap kegiatan, mengadakan rapat, mengambil keputusan, mengatur proses pembelajaran, mengatur administrasi, dan mengatur tata usaha, siswa, ketenagaan, sarana, dan prasarana, keuangan (Sabirin, 2012).Sunarto
(2011) menjelaskan bahwa kepala sekolah sebagai manajer dituntut memiliki kesiapan untuk mengelola sekolah, kemampuan dan kemauan muncul manakala para pemimpin sekolah dapat membuka diri secara luas untuk menyerap sumber-sumber yang dapat mendorong perubahan manajerial.Untuk melakukan peran dan fungsinya sebagai manajer, kepala sekolah harus memiliki strategi yang tepat untuk: a) memberdayakan tenaga kependidikan melalui kerjasama; b) memberi kesempatan kepada para tenaga kependidikan untuk meningkatkan profesinya; dan c) mendorong keterlibatan seluruh tenaga kependidikan yang menunjang program sekolah.Karena jika merujuk pada pandangan manajemen modern, kerjasama merupakan hal yang amat mendasar dalam sebuah organisasi.

3) Kepala sekolah sebagai administrator, kepala sekolah bertanggung jawab atas kelancaran segala pekerjaan dan kegiatan administratif di sekolahnya. Sunarto (2011) memaparkan bahwa kepala sekolah sebagai kategori administrasi pendidikan perlu melengkapi wawasan kepemimpinan pendidikan dengan pengetahuan dan sikap yang antisipatif terhadap perubahan yang terjadi dalam kehidupan masyarakat, termasuk kebijakan pendidikan.Sebagai seorang administrator, kepala sekolah harus memiliki kemampuan untuk memperbaiki dan mengembangkan semua fasilitas sekolah. Secara spesifik, kepala sekolah juga dituntut untuk mengelola kurikulum, mengelola administrasi sarana dan prasarana, mengelola administrasi kearsipan, dan mengelola administrasi keuangan 
(Purwati, 2013).Manajemen keuangan dapat diartikan sebagai tindakan pengurusan keuangan seperti pertanggung jawaban, dan pelaporan (Vivi, 2013).

4) Kepala sekolah sebagai supervisor, supervisi adalah kegiatan mengamati, mengidentifikasi mana hal-hal yang sudah benar, manayang belum benar, dan mana pula yang tidak benar, dengan maksud agar tepat dengan tujuan memberikan pembinaan (Arikunto, 2004; Barinto, 2012; Vivi, 2013).A.R., Manarus, \& Sidik (1996) ada hubungan positif yang signifikan antara supervisi kepala sekolah dan kepuasan kerja guru(Fanani, Mardapi, \& Wuradji, 2014).

5) Kepala sekolah sebagai leader, kepemimpinan kepala sekolah merupakan salah satu faktor yang dapat mendorong sekolah dapat mewujudkan visi, misi, tujuan dan sasaran sekolah melalui programprogram yang dilaksanakan secara terencana dan bertahap. Karena itu kepemimpinan adalah kegiatan mempengaruhi orang lain agar mau bekerja untuk mencapai tujuan yang telah ditentukan.Untuk kepentingan tersebut, kepala sekolah harus mampu mempengaruhi dan menggerakkan sumber daya sekolah dalam kaitannya dengan perencanaan dan evaluasi program sekolah, pengembangan kurikulum, pembelajaran, pengelolaan ketenagaan, sarana dan sumber belajar, keuangan, pelayanan siswa, hubungan sekolah dengan masyarakat, penciptaan iklim sekolah, dan sebagainya.

6) Kepala sekolah sebagai inovator, dalam rangka melakukan peran dan fungsinya sebagai inovator, kepala sekolah harus memiliki strategi yang tepat untuk menjalin hubungan yang harmonis dengan lingkungan, mencari gagasan baru, mengintegrasikan setiap kegiatan, memberikan teladan kepada seluruh tenaga kependidikan di sekolah dan mengembangkan modelmodel pembelajaran yang inovatif. Ancok (2012) memaparkan bahwa inovasi adalah suatu perubahan dari sesuatu hal, baik bersifat inkremental maupun perubahan yang bersifat radikal.Peran kepala sekolah sebagai inovator akan tercermin dari cara-cara ia melakukan pekerjaannya secara konstruktif, kreatif, delegatif, integratif, rasional dan obyektif, keteladanan, disiplin, serta adaptabel dan fleksibel.

7) Kepala sekolah sebagai motivator, kepala sekolah harus memiliki strategi yang tepat untuk memberikan motivasi kepada para tenaga kependidikan dalam melakukan berbagai tugas dan fungsinya. Karena kepala sekolah meyakini dengan kemampuan membangun motivasi yang baik akan membangun dan meningkatkan efektifitas dan efisiensi kerja (Sabirin, 2012; Purwati, 2013), sehingga bawahannya mampu berkreasi demi mewujudkan mutu pendidikan yang baik pula. Kemampuan kepala sekolah membangun motivasi menjadi salah satu kunci untuk meningkatkan mutu pendidikan karena dikaloborasikan dengan kinerja guru. Hasil penelitian Septiana, Ngadiman, \& Ivada (2013)menyimpulkan bahwa kepemimpinan kepala sekolah dan motivasi kerja secara bersama-sama berpengaruh signifikan terhadap kinerja guru.

Berdasarkan pemaparan peran kepala sekolah diatas disimpulkan bahwa peranan kepala sekolah sebagai fasilitator, motivator, dan supervisor harus memiliki upaya-upaya 
tertentu, misalkan: 1) mengikutsertakan guruguru dalam setiap kesempatan penataran dan latihan, tanpa melihat sisi kedekatan dan kekeluargaan secara personal dari kepala sekolah; 2) memberikan dorongan kepada guru untuk melanjutkan pendidikan lebih tinggi, karena kualifikasi guru yang memiliki jenjang pendidikan lebih tinggi tentu akan mempengaruhi mutu pendidikan yang dihadirkan dilingkungan sekolah, dan 3) membantu guru-guru yang mengalami kesulitan dalam mengelola proses belajar- mengajar.

\section{Langkah Selanjutnya Seperti Apa yang Harus Dilakukan Oleh Sang Kepala Sekolah?}

Terkait dengan tugas dan posisinya yang sangat strategis, maka kepala sekolah dituntut memiliki kreatifitas.Dengan demikian, untuk menjadi kreatif setiap kepala sekolah harus memiliki dua variabel utama, ide dan karya. Ide dan gagasan tanpa karya hanya akan menghasilkan mimpi-mimpi indah tanpa membawa perubahan, sebagaimana juga karya tanpa gagasan baru hanya akan menghasilkan stagnasi dan kejumudan (Rosyada, 2015).

Tugas kepala sekolah sebagai sangat kompleks, tidak sekedar mengelola kurikulum dan buku ajar, tapi juga SDM guru, staf tata usaha dan juga mengelola serta mengembangkan aset dan mengelola keuangan institusi. Dengan demikian, dia harus memiliki tiga kecerdasan, yakni kecerdasan profesional, kecerdasan personal dan kecerdasan manajerial (Rosyada, 2013). Demikian pula, kepala sekolah harus respek pada para siswanya, termasuk siswa yang tertinggal dalam penguasaan bahan-bahan ajar, agar tidak ada satu anak pun yang tertinggal oleh rombongan belajarnya. Tidak boleh membedakan layanan hanya karena perbedaan etnik, bahasa, budaya dan agama. Kepala sekolah harus memiliki rasa percaya diri untuk berhadapan dengan para pejabat daerah dan pusat, dan tidak boleh superior terhadap guru, staf dan seluruh jajaran pegawai di sekolahnya.

James (2013) memaparkan bahwa kepala sekolah harus melakukan lima aktivitas utama, antara lain: 1) merumuskan visi untuk kemajuan akademik siswa; 2) menciptakan suasana sekolah yang sangat kayak untuk pendidikan danpembelajaran; 3) menanamkan sikap kepemimpinan terhadap seluruh staf akademik dan non-akademik; 4) meningkatkan pembelajaran, dan 5) mengelola seluruh staf akademik dan non-akademik untuk mengelola proseslayanan akademik dan non-akademik dalam rangka mempercepat kemajuan.

Kepala sekolah harus merumuskan visi kepemimpinannya yang jelas dan terukur, dan dapat difahami oleh semua staf akademik dan non akademik sehingga mereka memahami apa yang harus dikerjakan sesuai visi kepala sekolahnya. Kemudian menciptakan suasana yang dapat mendukung pelaksanaan proses pembelajaran, memimpin seluruh stafnya, serta mengelola seluruh orang dan proses untuk mempercepat kemajuan sekolah.

Di samping itu semua, ada hal yang sangat krusial yang harus dilakukan kepala sekolah dalam rangka peningkatan kualitas pendidikan yang menjadi tanggung jawabnya, yakni peningkatan kualitas proses dan hasil belajar. Kunci utama peningkatan mutu tersebut adalah guru. Pendidikan yang baik harus ditopang oleh guru yang memiliki kapabilitas, loyalitas dan integritas, serta akuntabilitas pelaksanaan tugas. Artinya bahwa kepala sekolah harus memiliki komitmen kuat untuk mengembangkan, meningkatkan dan memelihara profesionalisme para guru di sekolahnya dengan cara melaksanakan supervise secara rutin.

Untuk itu, menurut Bredeson dan Johansson (2013) kepala sekolah harus melakukan beberapa langkah, antara lain: a) selalu melakukan analisis terhadap basil belajar siswa, ujian, dengan mengkaji perbedaan antara hasil belajar dengan tujuan; b) melibatkan guru 
dalam mengidentifikasi kebutuhan, danc) melakukan analisis apakah program-program yang sudah diorganisisr masih efisien untuk mengatasi masalahd.

Untuk meningkatkan kualitas sekolah, kepala sekolah sebagai manajer yang bertanggung jawab terhadap maju mundurnya satuan pendidikan yang menjadi wilayah otoritasnya, yang paling pertama harus dilakukannya adalah merumuskan visi kepemimpinannya, mempersiapkan sekolah yang layak untuk penyelenggaraan pendidikan dan pembelajaran, bersikap sebagai seorang leader di hadapan seluruh staf akademik dan non-akademik, dan mengoptimalkan layanan seluruh stafnya untuk mempercepat kemajuan.

Dan bersamaan dengan itu, kepala sekolah juga harus terus melakukan analisis terus menerus terhadap kesesuaian hasil belajar siswa dengan visi dan tujuan sekolah, kebutuhan siswa, kebutuhan studi lanjut, serta mengarahkan guru untuk menyesuaikan program pembelajaran dan proses pembelajaran dengan pencapaian visi tersebut, serta dengan berbagai variabel kebutuhan siswa untuk studi lanjut dan bahkan untuk mampu menyesuaikan diri dengan kehdupan sosial kemasyarakatan serta berbagai perubahan yang terjadai sangat cepat dalam kehidupan sosial.

\section{PENUTUP}

Berdasarkan pemaparan pada pembahasan, maka ada beberapa hal yang perlu disimpulkan guna untuk mempermudahkan ingatan kita dari sekian banyak yang dibahas, antara lain:

1) Kepala sekolah dituntut memiliki kemampuan untuk mentransformasikan ide dan imajinasi serta keinginan-keinginan besar menjadi kenyataan. Karena jika kepala sekolah hanya memiliki visi dan misi mendapatkan jabatan sebagai ambang kesombongan maka tunggulah kehancuran untuk sekolah yang dipimpinnya.

2) Sekolah itu berkualitas atau tidak sangat bergantung pada pola kepemimpinan kepala sekolah, karena dialah pimpinan tertinggi di sekolah dan dialah yang bisa mengambil keputusan dalam segala hal.

3) Peran kepala sekolah dalam meningkatkan mutu pendidikan, yang meliputi sebagai edukator, manajer, administrator, supervisor, leader, inovator, dan motivator.

4) Perannya yang sangat kompleks, maka kepala sekolah harus benar-benar melakukan monitoring dan evaluasi terhadap visi misi serta programprogram yang terlaksana. Sehingga mampu merumuskan dan menganalisis untuk program-program selanjutnya agar maksimal. Disisi yang lainpun kepala sekolah sebagai pemimpin tertinggi selalu melakukan evaluasi kinerja-kinerja guru, staf, dan lingkungan sekolah guna menarik perhatian masyarakat.

5) Konsep mutu pendidikan bukan semata-mata terfokus pada penyediaan faktor input pendidikan, akan tetapi lebih memperhatikan faktor dalam proses pendidikan. Selain itu, mutu pendidikan tergantung bagaimana kepala sekolah merekrut calon guru seseuai dengankompetensi dan kualitas diri dari guru, artinya bukan semata-mata memandang sistem kekeluargaan, kedekatan dan memiliki modal yang banyak. 


\section{DAFTAR PUSTAKA}

Ahmad, S. 2013. Faktor Penentu Keberhasilan Kepala Sekolah. Jurnal Penelitian DanEvaluasi Pendidikan, 17(1), 127 147.

Ancok, Djamaludin. 2012. Psikologi Kepemimpinan dan Inovasi. Jakarta: Erlangga.

A.R., A., Manarus, R., \& Sidik, H. 1996. Hubungan Supervisi Kepala Sekolah dengan Kepuasan Kerja Guru Sekolah Dasar. Jurnal Ilmu Pendidikan, 3(3), 189-199.

Arikunto, Suharsimi. 2004. Dasar-dasar Supervisi. Jakarta: Rineka Cipta.

Banun Sri, Yusrizal, Usman Nasir. (2016).

Strategi Kepala Sekolah Dalam Meningkatkan Mutu Pendidikan Pada Smp Negeri 2 Unggul Mesjid Raya Kabupaten Aceh Besar. Jurnal Administrasi Pendidikan Pascasarjana Universitas Syiah Kuala, 4(1), pp. 137147.

Barinto. 2012. Hubungan Kompetensi Guru Dan Supervisi Akademik Dengan Kinerja Guru Smp Negeri Se-Kecamatan Percut Sei Tuan. Jurnal Tabularasa PPS UNIMED. Vol.9 No.2, 201-214.

Busrin, D., Aunurrahman, \& Aswandi. 2014. Supervisi Pengawas Dan Kemampuan Manajerial Kepala Sekolah Dengan Kinerja Guru Smp Negeri Kota Pontianak. Jurnal Pendidikan Dan Pembelajaran, 3(6), 1-14.

Bredeson, Paul V.,dan Olof Johansson. 2013. The School Principal's Role in Teacher Professional Development. Journal of in Service Education, USA.

Colby, Jeanette, and Miske Witt. 2000.Defining Quality in Education. Working Paper Of Education Section, Program Division. New York: UNICEF.
Dharma, Surya. 2002. Paradigma Baru: Manajemen Sumber daya Manusia. Yogyakarta: Amara Books.

Fanani, Z., Mardapi, D., \& Wuradji, W. 2014. Model Asesmen Kepemimpinan Pembelajaran Kepala Sekolah Pendidikan Dasar. Jurnal Penelitian Dan Evaluasi Pendidikan, 18(1), 129-145.

Hanushek, A, Eric. 1981. Educadtion Policy Research - A Industry Perspective. Economic of Education Review, 1(3), 193-223

Harvey, James. 2013. The School Principal as Leader: Guiding Schools to Better Teaching and Learning, the Wallace Foundation.

Hersey, Paul \& Ken Blanchard. 2005. Management of Organizational Behavior: Utilizing Human Resources. New Jersey: Prentice Hall Inc., fourth edition.

Little, Priscilla M. 2007. The Quality ofSchoolAge Child Care in After-School Settings. Journal Child Care and Early Education, Research Connection, Columbia University.

Peraturan Pemerintah No. 13 tahun 2015, revisi atas Peraturan Pemerintah No. 19 tahun 2005.

Purwanti, Sri. 2013. Peran Kepemimpinan Kepala Sekolah Dalam Eningkatkan Disiplin Kerja Guru Dan Pegawai Di Sma Bakti Sejahtera Kecamatan Kongbeng Kabupaten Kutai Timur. eJournal Administrasi Negara. 1(1), 210-224.

Purwanti, K., Murniati,A.R. dan Yusrizal. 2014. Kepemimpinan Kepala Sekolah Dalam Meningkatkan Kompetensi Guru Pada SMP Negeri 2 Simeulue Timur. Jurnal Ilmiah Didaktika XIV(2), 390-400. 
Rivai, Veithzal. 2003. Kepemimpinan dan Perilaku Organisasi Edisi Kedua. Jakarta: PT. Raja Grafindo Persada.

Rosyada, Dede. 2013. Paradigma Pendidikan Demokratis, Sebuah Model pelibatan Masyarakat dalam Pendidikan. Jakarta: Prenada Media.

Rosyada, Dede. 2015. Creative Thinking. Kolom Rector UIN Syarif Hidayatullah Jakarta, Edisi3.

Rosdianti, R, Sri. 2013.Kepemimpinan Kepala Sekolah dalam Manajemen Kinerja Guru dan Peningkatan Mutu Pembelajaran: Studi Deskriptif pada Sekolah Menengah Kejuruan Swasta di Kota Bandung. Jurnal Kajian Pendidikan, 3(1), 93-106.

Rusmawati, Vivi. 2013. Peran Kepemimpinan Kepala Sekolah Dalam Upaya Meningkatkan Disiplin Kerja Guru Pada SDN 018 Balikpapan. E-Journal Administrasi Negara. 1(2), 395-409.

Sabirin. 2012. Perencanaan Kepala Sekolah

Tentang Pembelajaran. Jurnal Tabularasa PPS UNIMED, 9(1), 111128.

Sadili Samsudin. 2006. Manajemen Sumber Daya Manusia. Bandung: CV Pustaka Setia.

Samino, Suwardi. 2014. Kepemimpinan Kepala Sekolah Dalam Pengembangan
Lembaga Pendidikan Islam Kreatif SD Muhammadiyah Kota Madiun. Jurnal Manajemen Pendidikan, 9(2), 186 195.

Sedarmayanti. 2010. Manajemen Sumber Daya Manusia, Reformasi Birokrasi dan Manajemen Pegawai Negri Sipil. Bandung: PT RefikaAditama.

Sergiovanni. 1987. The Principalship: A Reflective Practice Perspective. Boston: Allyn and Bacon Inc.

Septiana, R., Ngadiman, \& Ivada, E. 2013. Pengaruh Kepemimpinan Kepala Sekolah dan Motivasi Kerja Terhadap Kinerja Guru SMP Negeri Wonosari. Jupe UNS, 2(1), 107-118.

Sunarto. 2011. Pengaruh Gaya Kepemimpinan Kepala Sekolah, Manajemen Berbasis Sekolah dan Iklim Organisasi Terhadap Kepuasan Kerja dan Kinerja Guru SMP di Wilayah Sub Rayon 04 Kabupaten Demak. Jurnal Analisis Manajemen,5(1), 17-29.

Slamet, PH. 2000. Manajemen Berbasis Sekolah. Jurnal Pendidikan dan Kebudayaan. Jakarta: Departemen Pendidikan Nasional.

Townsend, Diana \& Butterworth. 1992. Your Child's Scholl. New York: A Plime Book. 